\title{
Experiential Learning In Marketing Communications Courses: The Demarketing Of College Binge-Drinking
}

Susan G. Rozensher, Iona College, USA

David S. Seal, Iona College, USA

\begin{abstract}
The experiential learning approach has been gathering substantial momentum and support in educational circles. In the team-based experiential learning project presented here, which effectively integrated theory and application, students were charged with creating an integrated marketing communications plan to demarket binge drinking on the college campus. By focusing on a topic of considerable social importance and interest to students, this quasi-live case study served as a valuable learning tool which combined both "experience" and "reflection", and provided students with practical business experience in taking on the roles of members of a "new business" team working together to analyze facts, generate strategies and create an integrated, persuasive presentation.
\end{abstract}

Keywords: experiential learning, knowledge-transmission, marketing communications

\section{INTRODUCTION}

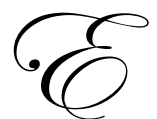

xperiential learning pedagogies have been increasingly adopted and integrated into the curricula of marketing courses over the past several years, as educators shift from the more traditional, "knowledgetransmission" model of education to a more interactive, experiential approach (special issue of the Journal of Marketing Education 2000; Frontczak and Kelley, 2000; Gremler et al 2000; Herbert 1995; Kennedy, Lawton, and Walker 2001; Smith and Van Dorne 2004). Indeed, when addressing the recent AACSB International Deans' Conference, Columbia University's business dean lamented that "...we have not undertaken the comparatively easy task of letting the business world ... see how we have embraced experiential learning" (Hubbard, 2007).

Unlike the conventional, teacher-centered approach that views the student as a passive, empty vessel awaiting knowledge from the teacher, the experiential approach is student-centered and considers the student's experience as primary (Frontczak 1998). Indeed, the professor relinquishes the role of "expert" for that of "facilitator" of students' participatory experience (Sims 2002; Duke 2002; Elam and Spotts 2004). Experiential methods are designed to encourage active student participation in and control of the learning process, and value the student's contributions to it (Frontczak 1998).

The experiential approach has been gathering substantial momentum and support in educational circles in general, and in schools of business in particular, for several reasons that have dovetailed. First, evidence for the success of the experiential approach has been mounting in a variety of settings, and on a number of measures. Specifically, the experiential approach has been linked to a deeper conceptual understanding of the subject matter and enhanced logical reasoning skills (Udovic et al 2002), an improved ability to connect theory with practice (Harich, 1995; Karns, 1993), enhanced student learning (Harich 1995; Butler and Laumer 1992), increased student responsibility for learning as a result of dealing with complex situations (Hernandez, 2002), and improvements in 
creativity (Livingstone and Lynch, 2002) as well as in communication and critical thinking skills (Lamb, Shipp, and Moncrief 1995; Harich 1995, Williams, Beard, and Rymer 1991).

Secondly, and no less importantly, students have weighed in on their views of the effectiveness of experiential learning and their interest in it, and the verdict is a strong vote of support. In a comprehensive study conducted at eight universities, live-case projects, internships, and field trips were rated as the most stimulating learning activities from a long list that included text/readings, guest speakers, online discussion, term papers, and more (Karns 2005). This was the case even though live-case projects and internships were also rated as requiring more effort relative to the other activities. Understandably, therefore, experiential learning activities have been linked to increased student motivation and involvement (House 2002; Udovic et al 2002; Butler and Laumer 1992; Williams, Beard and Rymer 1991; Harich 1995), and increased interest and enjoyment (Bobbitt, Inks, Kemp and Mayo, 2000). Students have found experiential learning to be more productive (Bobbitt, Inks, Kemp and Mayo 2000), and reported higher levels of confidence in their knowledge as a result of experiential learning (House 2002).

Although the significant growth in the use of experiential approaches has been recent, the pedagogical underpinnings were actually established in much earlier research on learning that harks back to Piaget's constructivist theories of child development (Piaget 1954), as well as Dewey's views on the centrality of experience to the learning process (1938). More recently, Kolb (1984) has mirrored and extended these theories, contending that "doing" (i.e. experience alone) does not have educational value unless it is accompanied by reflection. A number of studies seem to concur with this view that reflection is a necessary component in the successful deployment of any experiential learning exercise, because it is reflection that turns experience into experiential education (Joplin, 1995; Chapman, McPhee, and Proudman, 1995; Horwood, 1995). As Chapman, McPhee and Proudman (1995) stated, "Experiential learning combines direct experience that is meaningful to the student with guided reflection and analysis."

The team-based experiential learning project to be described here, centered on a quasi-live case study, is unique from a number of perspectives. First, the topic chosen for the project - creating an integrated marketing communications plan to demarket binge drinking on the college campus - is unusual and particularly interesting to students because it does not focus on a commercial product or service but rather, on an idea that has important social consequences and could possibly make a difference in students' lives. The topic generated enormous student involvement both inside and outside the classroom. Second, the pedagogical methods used to implement this project enable students to take on roles and function in a team designed to strongly mirror real-world business conditions. Third, this semester-long project offers a very valuable exercise in experiential learning by combining both "experience" and "reflection" at a number of so-called "checkpoints". Finally, the type of challenge students undertake in this project (developing a "new business pitch" with a considerable degree of complexity) is one they will likely encounter in the future, and therefore provides extremely useful preparation for any career in marketing. In sum, the project effectively integrates theory and application in a meaningful way, thus serving as a valuable learning tool.

\section{DESCRIPTION OF THE TEAM-BASED PROJECT ASSIGNMENT}

Students in undergraduate and graduate marketing communications classes were assigned the task of creating and presenting a new business "pitch" to a hypothetical client, "The Task Force on College Drinking", which is seeking help in discouraging binge drinking on college campuses. Students were instructed that they would be assigned to a five-member "new business team" of a small, highly creative advertising agency known for coming up with innovative, outrageous, and successful solutions to difficult communications problems. Their job was to convince the Task Force to retain their agency to advise them on an integrated marketing communications plan in the United States. Their specific objective was to demarket binge drinking on college campuses throughout the United States, and thereby diminish the negative consequences of this behavior.

Each team was expected to devise and present, by the end of the semester, an integrated marketing communications (IMC) plan including advertising, online marketing, "guerrilla marketing", and public relations. The campaign was to be directed primarily to students on American college campuses and, to some extent, other 
parties that are also affected by alcohol abuse in colleges. Importantly, the assignment was not to create an IMC campaign that seeks to convince college students to become teetotalers, but rather, to avoid binge drinking.

Students were told that the inspiration for creating this case study assignment came from the work of a highly creative advertising agency named Crispin Porter \& Bogusky, which was asked by the State of Florida to create an IMC campaign to discourage teens from smoking (cited in a "mini-case" in the textbook Advertising and Promotion, Belch and Belch, 2007). Initially, the campaign was limited to Florida, but when it proved so successful, the campaign was rolled out nationally. The results in Florida were dramatic - smoking among teenagers declined 38\% between 1998 and 2002. This campaign, named the "Truth" campaign, is an excellent example of how to discourage unhealthy behavior among young people. It seemed plausible that if an IMC campaign could diminish smoking among young people, it might similarly be possible to diminish binge drinking among college students. This was a formidable assignment, but one to which students could certainly relate. The students were told that if they could sell this idea, they could sell anything to anybody.

\section{FORMAT OF THE “NEW BUSINESS PITCH”}

In an effort to replicate the experience of participating in a real-world setting, the format of a "new business pitch" was adopted for the project and served as a quasi-live case study. Since advertising executives are often involved in new business presentations, this project provides students with valuable preparation for a career in marketing communications, and, in fact, in business in general.

Students were told that they should act just like a new business development team would act at a creative, professional advertising agency with multi-communications capabilities - advertising, online marketing, PR, promotion, media planning, and guerrilla marketing. They were given a specific assignment consisting of a statement of the problem, and background information to help them develop a communications strategy. They were told that they were competing for the "business", and the professor would ultimately "award" the account to the team deemed to have the most insightful strategy and the most creative executions of that strategy. Importantly, all members of the team would receive the same grade. This policy served to promote teamwork.

The format of a "new business pitch" provides numerous opportunities for experiential learning. The opportunities can be roughly divided into two parts: the development of specific skill sets, and exposure to areas of new knowledge. Among the more important skills learned are teamwork, presentation skills, strategizing, and creative thinking skills. The important areas of new knowledge for the students include a broad understanding of integrated marketing communications strategies, an understanding of how to integrate several parts of the IMC process toward specific communication goals, and a specific understanding of the problem of binge drinking among college students.

\section{RELEVANCE OF THE TOPIC SELECTED}

In addition to the general benefits of this experiential learning technique, there are also certain benefits to this case study which may not be present in many other cases. Specifically, the topic is highly relevant to students. Binge drinking is a plague on many college campuses and has become a part of the college culture in the United States. Every student is familiar with the subject and can converse on drinking quite easily. Class discussion on this topic was animated and detailed with many real-life stories. Some of the discussion was surprising and even shocking.

The tone the professor sets is quite important. It was made clear that the professor was not "preaching" to the students on the topic of binge drinking, and that the students would be treated as adults with respect to the material and their interpretation of it. In turn, the students were asked to do the same - not to moralize, to be objective, and to treat the assignment as if a real client had asked them to help solve a real problem. Initially, students were somewhat skeptical about 1) whether they wanted to convince their fellow classmates to refrain from binge drinking, and 2) whether it was even possible to do this. However, after students read the background material, a noticeable shift in attitudes occurred. Students were certainly aware beforehand of the problem of binge drinking on campus, but few had any real appreciation of the magnitude of the problem - how widespread it is and 
the seriousness of the fallout from binge drinking (student deaths, injuries, sexual assaults, problems with the law, poor class performance, alcoholism, etc.).

It was fortunate that students could be provided with a copy of the results of a survey of students on our campus that was conducted by the college and the SUIC/Core Institute (2005). It compares national findings with the results at our college. Certainly, this study had a significant impact on the students, and considerably enhanced the relevance of the topic. The students were also provided with numerous print ads about alcohol from magazines for youth. Quite a few additional references for background material were provided to the students. Articles on the following topics were included: a national survey of college binge drinking and the fallout from it, a study of the magnitude of alcohol-related deaths, injuries and other health problems among college students, a fact-sheet containing statistics on college binge-drinking, a study of the impact of heavy drinking on the adolescent brain, a fact-sheet on the impact of alcohol advertising and marketing, a number of studies by various public interest groups on alcohol advertising directed at teens, and articles about websites created by alcohol marketers.

This project can have some of the benefits of a live case study, and some significant payoff, if the administration of the college decides to implement the winning effort. We found our own campus' student counseling department to be enthusiastic about the idea, and we are discussing the possible implementation of some of the communications plans in a campus effort during Alcohol Awareness Week in an upcoming semester.

\section{THE TEAMS}

Students were formed into teams of five members, the ideal size for good interaction without becoming unwieldy. Additionally, a team of five allows each student to develop and present a significant portion of the presentation. Typically, a team in this project consisted of one student each assigned to the role of: President/Account Director, Research Director, Creative Director, Online Director, and Media/PR Director. The assignment of students to these roles adds a "real-world" excitement to the project, since the roles closely parallel those on typical teams that would undertake such a task.

All members of a team shared certain common responsibilities which included analyzing the background material, putting the information into a coherent and logical format, conceptualizing a profile of the target audience and the creative strategy, executing the creative strategy (i.e., developing mock TV commercials, radio commercials, print ads, an online program, and a PR/guerrilla marketing program), developing a mock media plan, and assembling all the components into a logical and persuasive presentation. Each member of the team also had the responsibility of presenting one part of their presentation to the rest of the class.

\section{STEP-BY-STEP APPROACH WITH CHECKPOINTS}

The students were given one week to review the background material and told to be ready to discuss the material for the next two classes. The first class focused on the facts and began with the question, "What did you think of the statistics that you read?" This type of open-ended approach usually leads to spirited discussion, and the professor should not put any judgmental guidelines on the conversation. (A note of caution: some students may have been victims - or perpetrators - of binge drinking episodes, such as assault or sexual assault. It's important to establish that no one is required to talk about any personal episodes and that this is not a morality lesson. The project is about gaining a deeper understanding of integrated marketing communications strategies and techniques.) At the end of the class, the students were told to gather with their team and discuss the facts, refer to their class notes, and develop a preliminary communications strategy. Specifically, they were told to come to the second class with a draft of:

1) A definition of the target audience, including key demographics and psychographics, and an understanding of the target audience's attitudes and behavior toward binge drinking. Students were also asked to conduct some qualitative research among their peers to develop this understanding.

2) The key selling idea for their campaign or, the "unselling idea", as it can be called in this case. 
3) A statement of the tonality of their IMC campaign. For example, should it be factual, funny, frightening, sympathetic, etc. Importantly, teams must have a rationale for each of the components of the preliminary communications strategy.

The second class discussion then focused on these IMC strategy drafts. Students were encouraged to comment on each team's strategies, saying why they might work or not. (Depending on the enthusiasm of the class, the professor can act as either a facilitator or can push the conversation harder.) Referring back to the facts of the case during the discussion is important, particularly when a team's rationale for their strategies seems insufficient. Ultimately, each team must demonstrate an understanding of the target market's attitudes and behavior and how to reach them with a persuasive "unselling idea" that has a strong chance of changing those attitudes and behavior.

At the end of the class, the teams were told they had four to five weeks to prepare their presentations, including mock creative work. They were also told that two weeks prior to the presentations, the professor would meet separately with each team for 20 to 30 minutes to review their ideas. This allowed for a mid-course correction, if necessary, and also allowed for students to report any problems with the equality of participation of some team members.

There are two important points to be made here. First, the setting of "checkpoints", when specific parts of the assignment were due, made it possible to reinforce the "reflective" part of the experiential learning process. Specifically, these "checkpoints" facilitated understanding of the marketing communications theories that the course is intended to convey by relating students' practical efforts ("experience") with the relevant theoretical concepts. At each step, the students were challenged to reflect on their points of view, analyze the facts again, and rethink their positions, taking marketing theory into account. Acting in teams, bouncing facts, statistics, and ideas back and forth, further reinforced the reflective aspect of the experiential learning process. The professor's responsibility was to facilitate an understanding of the connection between the students' practical efforts and the theories under discussion, pointing out (gently) how well the students' thinking and work reflected an understanding of those theories. The theories which are deemed of primary importance in this project are: a) an understanding of the target audience (demographics, psychographics, attitudes, behavior, and needs), b) the importance of developing a strong selling idea which answers the target's key needs and stands a chance of changing attitudes and behavior, and c) the creation of the right tonality or "character" of the IMC campaign which will facilitate the acceptance of the selling idea by the target audience.

\section{FINAL PRESENTATIONS}

Students were given guidelines for their final presentations, which were delivered using Power Point slides. The students were told to dress and act professionally, as if they were really conducting a presentation for a new piece of business. They were also instructed that only one person at a time should be presenting. The other team members were to be seated off to the side and introduced when their portion of the presentation was next. This guideline placed emphasis on smooth, logical segues from segment to segment. The presentations were to start with an introduction by the President of the New Business Team, who was supposed to give an overview of the situation. He or she would then introduce the Director of Marketing Research who would review the key facts and statistics which logically lead to a description of the target audience (demographics, psychographics, attitudes, behavior, and needs), followed by the creative strategy, the core selling idea, and the recommended tonality of the campaign.

The Director of Marketing Research would then introduce the Creative Director, who presented the mock advertising campaign. She or he would then introduce the Director of Online Marketing who presented the interactive portion of the IMC campaign. The last presenter, the Media Director, was supposed to present the mock media plan and the guerrilla marketing and PR campaign. Obviously, these responsibilities can be varied and allocated in several ways. After each presentation, the class members in the audience were encouraged to comment and ask questions. The professor should guide this part of the discussion. "Awarding the business" to one of the teams was deliberately held off for several days to build up some drama and encourage post-presentation discussion and reflection among students. The students enjoyed comparing strategies and mock creative work and talking about who was going to win the competition. While it was not done here, it is possible for the students to determine which team should be "awarded the business" by a vote. 
The final presentations demonstrated some strategic thinking that was insightful, logical, and actionable. The creative work was more uneven, ranging from the average to the extraordinary. Some of the work rivaled the creative talents of professional ad agencies. The quality of the presentations by some groups was quite professional, and the creative thinking included many good ideas. The work was impressive enough to have our campus' counseling department decide to pursue some of the ideas for a campus-wide alcohol awareness campaign in an upcoming semester.

\section{STUDENT REACTIONS AND REFLECTIONS AFTER COMPLETING THE COURSE}

A qualitative survey conducted after the course was completed indicated that students believed the project was of real value. Following are some quotes from students responding to our open-ended questions about how effective or ineffective the project was in helping them to develop each of the various abilities described below:

1. Teamwork Skills

"I thought the team project helped us to develop a great deal of teamwork skills. We had the opportunity to work in groups, just as we would in a real-life work situation..." "This project was great in testing my teamwork skills and improved how I cooperate in the workplace. Having each one of us act as a different position really reinforced what it is like in the real world. This project required the use of multiple skills and it really helped to learn how to balance strengths and weaknesses." "It was effective. You get to work with smart people, listen to new ideas, and sometimes even develop friendships from a task like this...especially a topic like this one, which is real, not made up."

2. Presentation Skills

"This project helped with my presentation skills...I am very shy and giving speeches terrifies me, so doing one in a group really helps me. I don't get as nervous as I would if I were doing it alone." "Having to present an involved, multi-step project improved my presentation skills." "We had to work with others to incorporate ideas and present our campaign...It helped us to practice our public speaking and presenting skills." "This topic was easy to relate to and it was easy to present and discuss. That helped me a lot."

3. Creativity

"Creatively, this project was fun, exciting and interesting." "This is the part I loved...It made you think outside the box and put you in the target market's shoes." "I am not a very creative person by nature, but seeing and listening to other student's ideas made me think more outside the box, and hopefully will help throughout this program and in real-life scenarios or projects."

4. Ability to Integrate Advertising, Promotion, Online Marketing, and Guerilla Marketing

"The class provided plenty of information to really take advantage of each promotional tool. I think this aspect really improved my understanding and capabilities of IMC." "This project helped us see that a marketing campaign must flow smoothly throughout all forms of media. I think it was very effective in helping us integrate all of the marketing tools." "I actually liked this campaign... because it allows you to tie-in advertising, promo, online marketing, and guerilla marketing...” “

5. Overall Understanding of Marketing Communications Strategies

You can pretty much market anything." "I feel that this project forced us to apply knowledge that we learned throughout the course with our own personal skills and qualities."

6. Understanding of Binge Drinking Among College Students

"It was actually very informative. The information that we were able to gather was shocking. I learned a lot of facts about college drinking and it really brought the problem to everyone's attention." "I understand binge drinking better than I did beforehand. I didn't realize how much of an issue it was until this project." "This was probably most shocking of all...It was a very valuable and informative project."

7. In What Other Ways, if any, did You Find the Project to be Meaningful or Worthwhile? 
"This was definitely worthwhile. It gave me a lot of experience in working on an advertising campaign, and I will definitely want to talk about it in an interview to get a job in advertising." "I found this project to be quite exciting and helpful. It really helped me combine all my skills. I was able to improve on my weaknesses and capitalize on my strengths." "It was worthwhile... a change from the usual business type of projects. It was something everyone (or almost everyone) can relate to..."

\section{Case Study Instructions for Students:}

\section{The "Unselling" of Alcohol Abuse on Campus}

\section{Statement of the Problem:}

- $\quad$ "Binge drinking" has become a common and serious problem on most college campuses. According to the Alcohol Policies Project, "College presidents agree binge drinking is the most serious problem on campus." The consequences of this behavior on college campuses have been terrible by any measure death, injury, assault, sexual abuse, unsafe sex, academic problems, health problems/suicide attempts, drunk driving, vandalism, property damage, police involvement and alcohol abuse and dependence. Source: The Task Force on College Drinking

\section{Hypotheses:}

- $\quad$ There exists a culture of heavy alcohol consumption on many college campuses.

- $\quad$ Students who engage in this self-destructive behavior have probably been influenced by several factors alcohol consumption at home, lack of education on the subject, drinking in high school, the prevalence of drinking on campus, peer pressure, stress, desire for status, and the ever-increasing marketing of alcoholic drinks by the beer and spirits industry.

- $\quad$ The beer and spirits industry deliberately targets impressionable young people, including underage consumers, in order to create loyal alcohol consumers at an early age

- $\quad$ Student attitudes on this subject will be hard to change and their behavior will be even harder to change. Education may be the one area of the problem most likely affected by a marketing communications campaign. And, as a result of more education on the subject, it is hoped that the peer pressure and the perceived status related to alcohol consumption will both diminish.

\section{Table of Contents:}

1. Introduction to the Subject and Fact Sheets

Provide students with specific articles and fact sheets to read (such as those provided by the Center for Science in the Public Interest).

2. Marketing Alcohol to Young People

Provide students with specific articles and fact sheets to read (such as those provided by the Center on Alcohol Marketing and Youth).

\section{The Project in Detail}

a) Statement of the assignment

b) Presentation format

c) Organization chart

d) Responsibilities of each team member

e) Advice

\section{a) The Assignment:}

Your group is the new business team of a small, highly creative advertising agency. You're known for thinking outside the box and coming up with outrageous and successful solutions to difficult communications problems. It is your job to convince the prospective client, the Task Force on College Drinking, that they should retain your agency to advise them about integrated marketing communications in the United States. Their specific objective is to decrease binge drinking on campuses throughout the U. S., and the resultant negative consequences of this behavior. 
You are expected to present an integrated marketing communications plan including advertising, online marketing, "guerrilla marketing", and public relations. It is directed primarily to students on U. S. college campuses and, to some extent, other parties which are also affected by alcohol abuse in colleges.

\section{b) Presentation Format:}

\section{Background}

a. Data and any trend analysis which demonstrates an understanding of the problem including, but not limited to, campus/alcohol related facts, sales and ad expenditures of alcohol industry leaders, examples of beer and spirits advertising specifically targeted to youth, etc.

b. Prime Prospect(s) (demographics, psychographics, behavioral characteristics, consumption trends, attitudes toward alcohol, etc.)

c. Strategic implications of the research results and suggested action

\section{Marketing Communications Objective}

"Convince college students that binge drinking is..."

\section{IMC Strategy:}

Target Audience (WHO are you talking to. Include demographics, psychographics, and relevant attitudinal and behavioral characteristics)

Creative Strategy (HOW you are going to accomplish the Marketing Communications Objective)

Creative Examples - (WHAT are you going to say. Creative, online, guerrilla marketing and PR. Demonstrate how they all coordinate to produce a strong "unselling" campaign. Examples of the creative strategy must include a TV storyboard, print ad, radio script, online ideas, guerrilla marketing ideas, and PR ideas. Your rationale for each of the ideas is critically important. "Here's the idea, here's why we think it's a good idea.

Summary and final remarks by the President

\section{c) Organization Chart:}

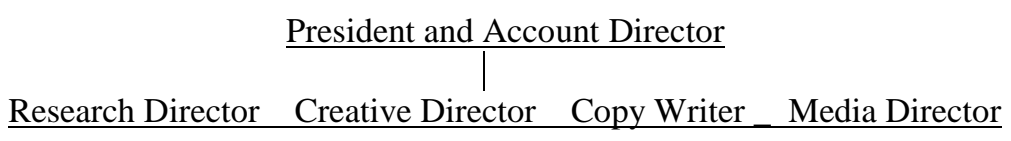

\section{d) Responsibilities of each team member:}

President and Account Director: Leader and coordinator of the entire project. Other team members report to him or her. Must present opening remarks, introduce team members, present agenda and give the overview of the project. After the Research Director gives the research results, the President presents the objectives and strategy, and positioning recommendation. Gives "wrap-up" speech, reviewing key points and recommendations.

Research Director: Presents marketing research results and recommended action based on the results. POV should logically lead into the objectives and strategy, and positioning recommendation which is then presented by the President and Account Director.

Creative Director and Copywriter: They present the IMC plan, including advertising campaign, online, guerrilla marketing and PR recommendations. The specific creative work that must be presented must include the following:

1) One :30 TV storyboard

2) One page, four-color print ad

3) One :60 radio commercial

4) One online marketing program that ties-in with the advertising program 
5) One guerrilla marketing and one PR idea program that also ties-in with the overall IMC program

Media Director: Staff position. Presents the media strategy and the rationale for the recommendation - but not an entire media plan. May give examples of the type of programming, magazines, websites, etc. that would be utilized.

\section{e) Advice:}

- Conduct some original research among the target audience to "get inside their heads". This research can be of a qualitative nature but must have enough people in the sample (10 or more) to have some validity. The purpose of the research is to help you understand attitudes on this subject, to generate ideas for the campaign and possibly to test some creative strategies.

- Make sure that the presentation of the background facts segues logically into the marketing communications objective and the creative strategy.

- Communicate how buying into this change of attitude and behavior toward alcohol benefits the target audience.

- Remember that consumers buy into an idea's values and well as its functional benefits. That may be even more true in this case.

- Create an emotional bond between the idea and the consumer.

- For the TV storyboard, remember to tell a good story. Use the medium's advantages of sight, sound, and motion to draw viewers in and then sell them.

- For the radio commercial, create memorable images in the listener's mind.

- For the print ad, use compelling visuals and headlines that work together to grab the reader's attention and sell them.

- Integrate the message into each aspect of the program. "Speak with one voice."

- Talk among yourselves - a lot. Bounce ideas around. The more communication, the better.

- Rehearse, dress, and act professionally in your presentation.

\section{AUTHOR INFORMATION}

Susan G. Rozensher is Associate Professor of Marketing at Iona College, New Rochelle, New York. She received her Ph.D. from Columbia University. She has published in numerous business journals, and her teaching and research interests include customer loyalty, customer-company identification, marketing research, and marketing education. Prior to her teaching career, she worked as an executive in the field of marketing research.

David S. Seal is an adjunct professor of marketing at Iona College, New Rochelle, New York. He received his MBA from NYU Graduate Business School. Prior to his career in teaching, he worked as a top executive for three of the most successful advertising agencies in the world - Ted Bates \& Company, Lintas Worldwide, and for the last 22 years, BBDO Worldwide. He retired as a Senior Vice President and Account Director at BBDO.

\section{REFERENCES}

1. Belch, George and Michael Belch 2007. Advertising and Promotion, Boston, Mass: Irwin/McGraw-Hill, pp. 67-69.

2. Butler, Daniel D. and J. Ford Laumer, Jr. 1992. Student attitudes toward marketing mix activities in the larger class environment. Journal of Marketing Education Fall, 40 - 46.

3. Bobbit, L. Michelle, Scott A. Inks, Katie J. Kemp, and Donna T. Mayo. 2000. Integrating marketing courses to enhance team-based experiential learning. Journal of Marketing Education 22 (1): 15-24.

4. "A Call to Action: Changing the Culture of Drinking at U. S. Colleges". Report by the Task Force on College Drinking, 2002.

5. Chapman, Steve, Pam McPhee and Bill Proudman 1995. What is experimental education? In The Theory of experiential education. K. Warren, M. Sakofs and J. Hunt, Eds. Dubuque, Iowa: Kendall-Hunt Publishing Company: $235-247$. 
6. Dewey, John. 1938. Experience and education. New York: Collier.

7. Drafke, Michael W., Denise D. Schoenbachler and Geoffrey L. Gordon. 1996. Active and passive teaching methodologies: Student outcomes over a semester course. Marketing Education Review 6 (Spring): 9-17.

8. Duke, C. 2002. Learning outcomes: Comparing student perceptions of skill level and importance. Journal of Marketing Education 24 (3): 203-17.

9. Elam, E., and H. Spotts. 2004. Achieving marketing curriculum integration: A live case study approach. Journal of Marketing Education 26 (1): 50-65.

10. Frontczak, Nancy T. and Craig A. Kelley. 2000. The Editor's Corner: Special issue on experiential learning in marketing education. Journal of Marketing Education 22 (1): 3-4.

11. Gentry, James W. 1990. What is experiential learning? In Guide to business gaming and experiential learning. James W. Gentry, ed., New York: Nichols/GP Publishing: 9-20.

12. Gremler, D., K. Hoffman, S. Keaveney, and L. Wright. 2000. Experiential learning exercises in services marketing courses. Journal of Marketing Education 22(1): 35-44.

13. Harich, Katrin. 1995. Experiential learning in business classes: Outcomes and challenges. College Student Journal, 29 (December): 409-413.

14. Hernandez, S. A. 2002. Team learning in a marketing principles course: Cooperative structures that facilitate active learning and higher level thinking. Journal of Marketing Education 24 (1), 73-85.

15. Herbert, Tom 1995. Experiential learning: A teacher's perspective. In Experiential learning in schools and higher education. R.J. Kraft and J. Kielsmeier, Eds. Dubuque, Iowa: Kendall-Hunt Publishing Company: 201-211.

16. Horwood, Bert. 1995. Reflections on reflection. In Experiential learning in schools and higher education. R.J. Kraft and J. Kielsmeier, Eds. Dubuque, Iowa: Kendall-Hunt Publishing Company: 227-229.

17. Hubbard, R.Glenn. February 2007. Remarks at AACSB International Deans Conference, Las Vegas, Nevada. Reported on AACSB website.

18. "Iona College: Core Alcohol and Drug Survey Long Form - Form 194. Executive Summary". Iona College and SUIC/Core Institute, 2005.

19. Joplin, Laura 1995. On defining experiential education. In The Theory of experiential education. K. Warren, M. Sakofs, J. Hunt, Eds. Dubuque, Iowa: Kendall-Hunt Publishing Company: 15-22.

20. Karns, G. 1993. Marketing student perceptions of learning activates: Structure, preferences, and effectiveness. Journal of Marketing Education 15 (1): 3-10.

21. Karns, Gary L. 2005. An Update of marketing student perceptions of learning activities: Structure, preferences, and effectiveness. Journal of Marketing Education 27 (2): 163-171.

22. Kennedy, Ellen J., Leigh Lawton, and Erika Walker. 2001. The case for using live cases: Shifting the paradigm in marketing education. Journal of Marketing Education 23 (2): 145-51.

23. Kolb, David A. 1984. Experiential learning: Experience as the source of learning and development. Englewood Cliffs, NJ: Prentice Hall.

24. Lamb, C., Jr., S. Shipp, and W. Moncrief III. 1995. Integrating skills and content knowledge in the marketing curriculum. Journal of Marketing Education 17 (3): 10-19.

25. Livingstone, D. and K. Lynch 2002, Group project work and student centered active learning: Two different experiences. Journal of Geography in Higher Education 26 (2): 217-317.

26. Piaget, Jean 1954. The Construction of reality in the child. New York: Basic Books.

27. Sims, R.R. 2002. Teaching business ethics for effective learning. Westport, CT: Quorum Books.

28. Smith, L., and D. Van Doren. 2004. The Reality-based learning method: A simple method for keeping teaching activities relevant and effective. Journal of Marketing Education 26 (1): 66-74.

29. Udovic, D., D. Morris, A. Dickman, J. Poslethwait, and P. Wetherwax. 2002. Workshop Biology: Demonstrating the Effectiveness of Active Learning in an Introductory Biology Course, Bioscience, 52 (3): 272-281.

30. Williams, David L., John D. Beard and Jone Rymer. 1991. Team projects: Achieving their full potential. Journal of Marketing Education (Summer): 45-53.

31. Wright, L., M. Bitner, and V. Zeithamel. 1994. Paradigm shifts in business education: Using active learning to deliver services marketing content. Journal of Marketing Education 16 (3): 5-19. 